\title{
Kan Kültüründe Kalite Yönetim Sisteminin Önemi: Kontaminasyon Oranları
}

\section{Importance Of Quality Management System in Blood Culture: Contamination Rates}

\author{
Nuray $A R{ }^{* 1} \square$, Emine YEŞiLYURT ŞÖLEN²ロ, NezihaYILMAZ
}

1'istanbul Sultanbeyli Devlet Hastanesi, Tıbbi Mikrobiyoloji Birimi, İstanbul, Türkiye

${ }^{2}$ Yozgat Bozok Üniversitesi, Tıp Fakültesi, Tıbbi Mikrobiyoloji Anabilim Dalı, Yozgat, Türkiye

3Ufuk Üniversitesi, Tıp Fakültesi, İnfeksiyon Hastalıkları Anabilim Dalı, Ankara, Türkiye

\section{öz}

Amaç: Kan dolaşımı enfeksiyonlarının tanısı, klinik mikrobiyoloji laboratuvarlarının en acil ve önemli görevlerinden biridir. Kontaminasyonu en aza indirerek doğru etkenin saptanması morbidite ve mortaliteyi doğrudan etkilemektedir. Bu çalışmamızda, kan kültürlerinde kontaminasyona neden olan preanalitik etkenlerin belirlenmesi amaçlanmıştır.

Gereç ve Yöntemler: Mikrobiyoloji Laboratuvarına 17.05.2017-08.11.2019 tarihleri arasında gelen örnekler otomatize kan kültürüne ekildi. Üreme sinyali veren örnekler boyama sonrası bakteriyel kültür yapılarak otomatize sistemle identifikasyon ve antibiyograma alındı. Sonuçlar kan dolaşım yolu enfeksiyonuna neden olduğu bilinen etkenler ve kontaminantlar açısından analiz edildi.

Bulgular: Toplam 5215 kan kültür örneğinin $821(\% 15,7)$ 'nde üreme saptandı. Örneklerin $425(\% 8,15)^{\prime}$ i kontaminant olarak rapor edildi. Kontaminasyon oranı kadınlarda \%8,7; erkeklerde \%7,8 idi. Yaş gruplarına göre kıyaslandığında oran 18 yaş üstü grupta en yüksek $(\% 9,3)$ iken 5-18 yaş grubunda en düşüktü $(\% 3,4)$. Servis olarak Yoğun Bakımlarda kontaminasyon oranının en fazla $(\% 13,8)$ olduğu görüldü.

Sonuç: Kontaminasyon; kanda organizma olmadığı halde kültürde üreme olması durumudur ve en önemli nedeni, cilt florasında bulunan mikroorganizmaların kan kültürü şişelerine inokülasyonudur. Hastane ortamı, kateteri kolonize eden mikroorganizmalar, kanı alan personelin elleri ve kültür alımında kullanılan ekipmanlar da kontaminasyon kaynağı olabilir. Bizim çalışmamızda kontaminasyon oranlarını yüksekti ve yaş grupları ile servisler arasındaki fark anlamlı bulduk. Kontaminasyon oranlarının düşürülmesi için kan eğitimli bir sağık personeli tarafından alınmalı, etkin bir cilt antisepsisi uygulanmalı ve intravenöz kataterden örnek alınmamalıdır.

Anahtar kelimeler: Kan kültürü; kontaminasyon oranı; kalite göstergeleri

Sorumlu Yazar*: Nuray ARI, İstanbul Sultanbeyli Devlet Hastanesi, Tıbbi Mikrobiyoloji Birimi, İstanbul, Türkiye 


\section{ABSTRACT}

Aim: Diagnosis of bloodstream infections is very important for microbiology. Determining the correct agent by minimizing contamination directly affects morbidity and mortality. In this study, it was aimed to determine the preanalytical factors causing contamination in blood cultures.

Material and Methods: The samples that sent to Microbiology Laboratory between 17.05.2017-08.11.2019 were added to automated blood culture. Reproductive signal samples were stained and bacterial cultures were made.

Results: Bacterial growth was detected in $82(15.7 \%)$ of 5215 culture samples. $425(8.15 \%)$ of the samples were contaminants. This rate were $8.7 \%$ in women; $7.8 \%$ in men. In age groups, the ratio was highest above the age of $18(9.3 \%)$; It was the lowest at the age of 5-18(3.4\%). In services, the rate of contamination in intensive care units was highest (13.8\%).

Conclusion: Contamination is the growth in culture, although there is no organism in the blood. The most important reason is the inoculation of microorganisms in the skin flora into culture bottles. Hospital environment, microorganisms that colonize the catheter, the hands of the staff who take the blood and the equipment used to take culture can also be a source of contamination. In our study, contamination rates were high and we found the difference between age groups and services significant In order to reduce the contamination rates, blood should be taken by a trained healthcare professional, an effective skin antisepsis should be applied and sample should not be taken from the intravenous catheter.

Keywords: Blood culture; contamination rate; quality indicators

\section{Giriş}

Hastane kaynaklı kan dolaşım enfeksiyonları, en yaygın nozokomiyal enfeksiyonlar arasındadır [1]. Hastane enfeksiyonlarına yönelik koruma ve kontrol önlemlerine ve tıp alanındaki ilerlemelere rağmen halen hastalar için en önemli mortalite ve morbidite nedenlerinden biri olmaya devam etmektedir [2]. Kan dolaşım enfeksiyonlarının tanısı, klinik mikrobiyoloji laboratuvarlarının en acil ve önemli işlerinden biridir. Gerçek etkenlerin saptanması ve tüm pozitif bulguların olabildiğince hızlı bir şekilde klinisyene bildirilmesi, ampirik tedaviden etkene yönelik tedaviye geçiş süresini azaltarak morbidite ve mortaliteyi doğrudan etkilemektedir. Hızlı tanı için nükleik asit probları ve polimeraz zincir reaksiyonu (PZR) gibi çeşitli moleküler teknikler geliştirilmiştir. Ancak kan kültürü; bakteriyemi ve sepsise yol açan etken mikroorganizmaların saptanması ve izole edilebilmesi için hala en duyarlı ve güvenilir laboratuvar tanı yöntemi olmaya devam etmektedir $[3,4,5]$. Tanıda kan kültürü şişelerindeki $\mathrm{CO} 2, \mathrm{pH}$ ve redoks potansiyeli değişikliklerinin floresan veya kolorimetrik yöntemlerle saptanması temeline dayanan hızlı ve otomotize kan kültür sistemleri kullanılmaya başlanmıştır. Bu sistemler, inkübasyon süresini kısaltma, pozitiflik oranını arttırma, kontaminasyon riskini azaltma ve kullanım kolaylığı gibi avantajlara sahip yöntemlerdir [3]. Ancak yöntemin hassasiyeti nedeniyle cilt antisepsisinin ve şişe kapağı dezenfeksiyonunun uygun yapılmadığı durumlarda, kan kültür şişelerinin zengin besiyeri içeriği nedeniyle kontaminasyon oranlarında artış görülmektedir [6]. Pozitif kan kültürlerinin büyük kısmı gerçek kan dolaşımı enfeksiyonlarına bağlıdır. Üreyen mikroorganizmaların en kısa sürede saptanarak etken veya kontaminasyon olup olmadığının ortaya konması gerekir. Etken olarak kabul edilen mikroorganizmanın antibiyotik duyarlılık testlerinin yapılarak tedavinin doğru yönlendirilmesi, mortalite, morbidite ve sağlık giderlerinin azaltılmasında çok önemlidir [7].

Kan örneğinde kontaminant olabilecek mikroorganizmalar ürediğinde ve çeşitli nedenlerle birden fazla örneğin alınamadığı durumlarda klinik mikrobiyoloji laboratuvarı için gerçek etken olup olmadığını belirlemek önemli bir sorundur. Hastanın klinik durumuna, şüphelenilen enfeksiyona ve tedavinin aciliyetine göre alınması gereken ideal kan kültürü seti sayısı değiş̧ebilir. Tek kan kültürü seti yeterli değildir ve yeni doğan dönemi hariç önerilmez. Kan kültüründe ürediğinde kesin olarak etken kabul edilen bir patojen (Salmonella türleri, Brucella türleri, vb) izole edilmedikçe, tek bir pozitif kültür sonucunun yorumlanması zordur. Tek kan kültürü şişesi, koagülaz negatif stafilokoklar ve gram pozitif basiller gibi olası kontaminantların gerçek bakteriyemi etkenlerinden ayırt edilmesini de sağlayamamaktadır [8].

Mikroorganizmanın cinsi, örnekteki mikroorganizma yükü, mikroorganizmaların üreme sürelerinin farklı olması ve örneğin oda ısısında bekleme süresi gibi değişkenlerin de sonuç verme süresini etkilediği düşünülürse bu örneklerin raporlanmasında zorluklar meydana gelir. Kan kültürü sonuçlarının hızlı ve doğru yorumlanması; etkenlerin mümkün olan en kısa 
sürede saptanmasını, antibiyotik duyarlılık testlerinin doğru raporlanarak tedavinin doğru yönlendirilmesini sağlar [4]. Bu nedenle kan kültürleri ile ilgili kalite göstergeleri sürekli olarak izlenmeli ve gerektiğinde doğru uygulamaların yapıımasını sağlamak için kan kültürlerinin alınışı ve laboratuvarda yapılan işlemler ile ilgili önlemler alınmalıdır.

Kan kültürü kalite yönetim sistemi içerisinde gösterge olarak kullanılan parametrelerden birisi kontaminasyon oranlarıdır ve hastanelerde \%3'ün altında olmalıdır [7]. Bu çalışmamızda, kan kültürlerinde kontaminasyona neden olabilen preanalitik etkenlerin belirlenmesi amaçlanmıştır.

\section{Gereç ve Yöntemler}

Bozok Üniversitesi Tıp Fakültesi Mikrobiyoloji Laboratuvarına 17.05.2017-08.11.2019 tarihleri arasında gelen örnekler otomatize kan kültürü sistemi (BACT/ALERT) ile incelendi. Üreme sinyali veren örnekler boyama sonrası bakteriyel kültür yapılarak değerlendirildi. Birden fazla kan kültürü setinin sadece birinde cilt flora elemanlarının üremesi ve hastanın bu organizma ile enfeksiyonuna dair klinik veya laboratuvar kanıtının bulunmaması kontaminasyon olarak kabul edildi. Olası etkenler otomatize sistem (Vitek-2 Biomerieux, France) ile identifikasyon ve antibiyograma alındı. Kan dolaşım enfeksiyonuna neden olduğu bilinen etkenler ve kontaminantlar yaş, cinsiyet ve klinik branşlar açısından analiz edildi.

\section{Bulgular}

Toplam 5215 kan kültürörneğinin $821(\% 15,7)$ 'inde pozitifsinyal saptandı. Bu örneklerin 396 (\%7.59)'sı etken patojen olarak 425 $(\% 8,15)^{\prime} \mathrm{i}$ ise kontaminant olarak rapor edildi. Kontaminasyon oranı kadınlarda $\% 8,7$ iken erkeklerde $\% 7,8$ olarak bulundu. Yaş gruplarına göre kıyaslandığında kontaminasyon oranı 18 yaş üstü grupta en yüksek $(\% 9,29)$ iken, 5-18 yaş grubunda en düşük $(\% 3,45)$ olarak bulundu. Klinik branşlar arasında ise Yoğun Bakım ve Acil Servislerde kontaminasyon oranlarının en fazla $(\% 13,79$ ve \%15,29) olduğu görüldü (Tablo1 ve 2).

\begin{tabular}{|c|c|c|c|c|c|c|c|c|c|}
\hline \multirow{3}{*}{ Yaş Grupları } & \multicolumn{3}{|c|}{ Kadın } & \multicolumn{3}{|c|}{ Erkek } & \multicolumn{3}{|l|}{ Genel } \\
\hline & \multirow{2}{*}{ Toplam Sayı } & \multicolumn{2}{|c|}{ Kontaminasyon } & \multirow{2}{*}{ Toplam Sayı } & \multicolumn{2}{|c|}{ Kontaminasyon } & \multirow{2}{*}{ Toplam Sayı } & \multicolumn{2}{|c|}{ Kontaminasyon } \\
\hline & & Sayı & $\%$ & & Sayı & $\%$ & & Sayı & $\%$ \\
\hline $0-1$ & 361 & 26 & 7,20 & 593 & 49 & 8,26 & 954 & 75 & 7,86 \\
\hline $1-5$ & 307 & 23 & 7,49 & 396 & 27 & 6,82 & 703 & 50 & 7,11 \\
\hline $5-18$ & 225 & 3 & 1,33 & 296 & 15 & 5,07 & 521 & 18 & 3,45 \\
\hline $18-+$ & 1049 & 117 & 11,15 & 1988 & 165 & 8,30 & 3037 & 282 & 9,29 \\
\hline Toplam & 1942 & 169 & 8,70 & 3273 & 256 & 7,82 & 5215 & 425 & 8,15 \\
\hline
\end{tabular}

\begin{tabular}{|c|c|c|c|c|c|c|c|c|c|}
\hline \multirow{3}{*}{ Servisler } & \multirow{3}{*}{ Toplam Sayı } & \multicolumn{2}{|c|}{ Kadın } & \multicolumn{3}{|c|}{ Erkek } & \multicolumn{3}{|c|}{ Genel } \\
\hline & & \multicolumn{2}{|c|}{ Kontaminasyon } & \multirow{2}{*}{ Toplam Sayı } & \multicolumn{2}{|c|}{ Kontaminasyon } & \multirow{2}{*}{ Toplam Sayı } & \multicolumn{2}{|c|}{ Kontaminasyon } \\
\hline & & Sayı & $\%$ & & Sayı & $\%$ & & Sayı & $\%$ \\
\hline Yoğun B & 551 & 82 & 14,88 & 943 & 124 & 13,15 & 1494 & 206 & 13,79 \\
\hline Dahili S & 408 & 33 & 8,09 & 577 & 28 & 4,85 & 985 & 61 & 6,19 \\
\hline Pediatri & 634 & 31 & 4,89 & 909 & 64 & 7,04 & 1543 & 95 & 6,16 \\
\hline Enfeksiyon & 125 & 5 & 4,00 & 294 & 8 & 2,72 & 419 & 13 & 3,10 \\
\hline Göğüs & 33 & 0 & 0,00 & 119 & 3 & 2,52 & 152 & 3 & 1,97 \\
\hline Cerrahi Branşlar & 120 & 5 & 4,16 & 332 & 16 & 4,81 & 452 & 21 & 4,64 \\
\hline Acil & 71 & 13 & 18,31 & 99 & 13 & 13,13 & 170 & 26 & 15,29 \\
\hline Toplam & 1942 & 169 & 8,70 & 3273 & 256 & 7,82 & 5215 & 425 & 8,15 \\
\hline
\end{tabular}

\section{Tartışma}

Kan dolaşım enfeksiyonları tıp alanında ki büyük ilerlemelere rağmen, modern dünyada büyük bir halk sağlığı problemi olmaya devam etmektedir [1]. İnvaziv girişimler, immünsüpresyon uygulanan hastaların artması ve hastanede yatış sürelerinin uzaması gibi nedenler bu tür enfeksiyonlara yol açabilmektedir. Pek çok çalışmada; kan dolaşım enfeksiyonu olan hastaların yaklaşık \%30'unun uygunsuz ampirik antimikrobiyal tedavi aldığı ve bu durumun endişe verici boyutlarda olduğu vurgulanmaktadır [9-12]. 
Kan kültürlerinde patojen etkenin mümkün olan en kısa süre içinde saptanması, tedaviye zamanında başlanmasını sağlamakta ve mortalite ve morbiditeyi önemli oranda azaltmaktadır [4]. Ancak deri antisepsisi uygun olarak yapılmadığında ve özellikle tek kan kültürü şişesine örnek alındığında kontaminant bakteriler üremekte ve bu üremeler için etken-kontaminasyon ayrımını yapmak zorlaşmaktadır. Kontaminasyon, kanda organizma olmadığı halde kültürde üreme olması durumudur ve en önemli nedeni, cilt florasında bulunan mikroorganizmaların kan kültürü şişelerine inokülasyonudur [16]. Yapılan çeşitli çalışmalarda, etken olarak belirlenen organizmaların ortalama üreme süreleri, erişkin yaş grubunda Gram pozitif bakteriler için 18-19 saat, Gram negatif bakteriler için 15-19 saat, mayalar için 23-41 saat olarak saptanmış; pediatrik yaş grubu için bu değer ortalama 23 saat olarak bulunmuştur. Etken mikroorganizmaların ilk 24 saat içinde üreme oranları ise \%68-90 olarak bildirilmiştir. İki farklı çalışmada, sıklıkla kontaminant olduğu düşünülen KNS'nin ortalama üreme süreleri 24-29 saat olarak saptanmış ve etken olduğu düşünülen diğer gram-pozitif bakterilere kıyasla daha geç üredikleri belirlenmiştir [13, 14, 15]. Al-Hamad [17] ve arkadaşlarının yaptığı çalışmada personel eğitimi öncesi ve sonrası kontaminasyon oranları sırasıyla \%8,1 ve \%5,2 (\% 36 azalma) bulunmuştur. Panday [19] ve arkadaşlarının 2019 yılında yapmış olduğu çalışmada kültür pozitifliği \%13,9 iken kontaminasyon oranları \%7,4 olarak bulunmuş. Bizim çalışmamızda ise \%15,7 olan kültür pozitifliğinin \%8,15'i kontaminasyon olarak değerlendirildi. Bu oran kalite yönetim sistemi gösterge standartlarına göre yüksek bulundu.

Kontaminasyon oranı cinsiyete göre değerlendirildiğinde, kadınlarda erkeklerden yüksek olduğu görüldü ve bu istatiksel olarak anlamsızdı. Yaş gruplarına göre değerlendirildiğinde 5-18 yaş arası kontaminasyon oranı en düşüktü ve bu istatiksel olarak anlamlı bulundu. Yoğun bakım ve acil servislerden alınan kanlardaki kontaminasyon oranı diğer servislerden daha yüksek olduğu görüldü ve bu istatiksel olarak anlamlı bulundu. Yaş grupları ve servislere göre anlamlı istatistiksel farkın eğitimli personelin sürekli değişiminden kaynaklanabileceği düşünüldü (Tablo 3).

\begin{tabular}{|c|c|c|c|c|c|c|c|}
\hline & & \multicolumn{4}{|c|}{ Kontaminasyon } & \multicolumn{2}{|c|}{ Test } \\
\hline & & \multicolumn{2}{|c|}{ Var } & \multicolumn{2}{|c|}{ Yok } & \multirow{2}{*}{$\times 2$} & \multirow{2}{*}{$P$} \\
\hline & & $\mathrm{n}$ & $\%$ & $n$ & $\%$ & & \\
\hline \multirow[b]{2}{*}{ Cinsiyet } & Kadın & 169 & 8,7 & 1773 & 91,3 & \multirow{2}{*}{1,263} & \multirow{2}{*}{0,261} \\
\hline & Erkek & 256 & 7,8 & 3017 & 92,2 & & \\
\hline \multirow{4}{*}{ Yaş } & $0-1$ & 75 & 7,9 & 879 & 92,1 & \multirow{4}{*}{21,691} & \multirow{4}{*}{0,000} \\
\hline & $1 y-5 y$ & 50 & 7,1 & 653 & 92,9 & & \\
\hline & $5 y-18 y$ & 18 & 3,5 & 503 & 96,5 & & \\
\hline & $18 y-+$ & 282 & 9,3 & 2755 & 90,7 & & \\
\hline \multirow{7}{*}{ Servisler } & Yoğun B & 206 & 13,8 & 1288 & 86,2 & \multirow{7}{*}{116,708} & \multirow{7}{*}{0,000} \\
\hline & Dahili S & 61 & 6,2 & 924 & 93,8 & & \\
\hline & Pediatri & 95 & 6,2 & 1448 & 93,8 & & \\
\hline & Enfeksiyon & 13 & 3,1 & 406 & 96,9 & & \\
\hline & Göğüs & 3 & 2 & 149 & 98 & & \\
\hline & Cerrahi Branşlar & 21 & 4,6 & 431 & 95,4 & & \\
\hline & Acil & 26 & 15,3 & 144 & 84,7 & & \\
\hline
\end{tabular}

\section{Sonuç}

Kontaminasyon oranlarını en aza indirebilmek için kan kültürleri ile ilgili kalite göstergeleri sürekli olarak izlenmeli, süreçlerle ilgili önlemler alınmalıdır. Hastane ortamı, kateteri kolonize eden mikroorganizmalar, kanı alan personelin elleri ve kan kültürü alımında kullanılan ekipmanlar kontaminasyon kaynağı olabilir. Etkin cilt antisepsisi uygulamak ve mevcut intravenöz kateterlerden kan kültürü almamak kontaminasyonun önlenmesinde en önemli faktörlerdir. Bu nedenle kan kültürünün eğitilmiş sağlık personeli tarafından alınması kontaminasyon oranlarının düşürülmesinde anahtar rol oynamaktadır.

\section{Çıkar çatışması/finansal destek beyanı}

Bu yazıdaki hiçbir yazarın herhangi bir çıkar çatışması yoktur. Yazının herhangi bir finansal desteği yoktur. 


\section{Kaynaklar}

1. Kaye KS, Marchaim D, Chen TY, et al. Effect of nosocomial bloodstream infections on mortality, length of stay, and hospital costs in older adults. J Am Geriatr Soc, 2014; 62: 306-11.

2. Lambert ML, Suetens C, Savey A, et al. Clinical outcomes of health-care-associated infections and antimicrobial resistance in patients admitted to European intensive-care units: a cohort study. Lancet Infect Dis, 2011; 1: 30-8.

3. Jian-nong WU, Tie-er GAN, Yue-xian ZHU, et al. Epidemiology and microbiology of nosocomial bloodstream infections: analysis of 482 cases from a retrospective surveillance study. Biomed \& Biotechnol, 2015; 16: 70-7.

4. Ntusi N, Aubin L, Oliver S, et al. Guideline for the optimal use of blood cultures. S Afr Med J 2010; 100: 839-43.

5. Chiarini A, Palmeri A, Amato T, et al. Detection of bacterial and yeast species with the Bactec 9120 automated system with routine use of aerobic, anaerobic, and fungal media. J Clin Microbiol 2008; 46: 4029-33.

6. Hall KK, Lyman JA. Updated review of blood culture contamination. Clin Microbiol Rev 2006; 19: 788-802.

7. Kan kültürü uygulama kılavuzu Ahmet Başustaoğlu 2013;11.

8. Tıbbi mikrobiyoloji uzmanları için klinik örnekten sonuç raporuna uygulama rehberi kan dolaşımı örnekleri eylül 2017; 16.

9. Anonymous. Clinical and Laboratory Standards Institute: Performance Standards for Antimicrobial Susceptibility Testing; Twenty First Informational Supplement. M100-S25. ISBN: 1-56238-989-0, Wayne, CLSI, 2015.

10. Sogaard M, Norgaard M, Dethlefsen C, et al. Temporal changes in the incidence and 30- day mortality associated with bacteremia in hospitalized patients from 1992 through 2006: a populationbased cohort study. Clin Infect Dis, 2011; 52: 61-9.

11. Sharma DK, Tiwari YK, Vyas N, et al. An investigation of the incidence of nosocomial infections among the patients admitted in the intensive care unit of a tertiary care hospital in Rajasthan. Int J Curr Microbiol, 2013; 2: 428- 35.
12. Fram $D$, Okuno MFP, Taminato $M$, et al. Risk factors for bloodstream infection in patients at a Brazilian hemodialysis center: a case-control study. BMC Infect Dis. 2015; 15: 158.

13. Durmaz G, Us T, Aydinli A, et al. Optimum detection times for bacteria and yeast species with the BACTEC 9120 aerobic blood culture system: evaluation for a 5 -year period in a Turkish university hospital. J Clin Microbiol 2003; 41: 819-21.

14. Janjindamai W, Phetpisal S. Time to positivity of blood culture in newborn infants. Southeast Asian J Trop Med Public Health 2006; 37: 171-6.

15. Gopi A, Ravikumar KL, Ambarish MG, et al. Time to positivity of microorganisms with BACTEC 9050: an 18-month study among children of 28 days to 60 months in an South Indian tertiary hospital. Intl J Microbiol Res 2011; 2: 12-7.

16. Roh KH, Kim JY, Kim HN, et al. Evaluation of BACTEC Plus aerobic and anaerobic blood culture bottles and BacT/Alert FAN aerobic and anaerobic blood culture bottles for the detection of bacteremia in ICU patients. Diagn Microbiol Infect Dis, 2012; 73: 239-42.

17. Arif Al-Hamad, Maha El-ibrahim, Eman Alhajhouj, et al. Nurses' competency in drawing blood cultures and educational intervention to reduce the contamination rate. Journal of Infection and Public Health, 2016; 1: 66-74

18. Goto M, Al-Hasan MN. Overall burden of bloodstream infection and nosocomial bloodstream infection in North America and Europe. Clin Microbiol Infect, 2013; 19: 501-9.

19. R. S. Nannan Panday, S. WangP. M. van de Ven, T. A. M. Hekker, N. Alam, P. W. B. Nanayakkara. Evaluation of blood culture epidemiology and efficiency in a large European teaching hospital Published: March 21, 2019 https://doi.org/10.1371/ journal.pone.0214052 